\title{
Overview and Checklist of Parasitoids (Hymenoptera, Braconidae and Figitidae) of Anastrepha Fruit Flies (Diptera, Tephritidae) in the Brazilian Amazon
}

\author{
Maria do Socorro Miranda de Sousa ${ }^{1}$, Jhulie Emille Veloso dos Santos ${ }^{2}$, \\ Dori Edson $\mathrm{Nava}^{3}$, Roberto Antonio Zucchi ${ }^{4}$ and Ricardo Adaime ${ }^{5^{*}}$ \\ ${ }^{1}$ Universidade Federal do Amapá, Programa de Pós-graduação em Biodiversidade Tropical, Macapá, \\ Amapá, Brazil. \\ 2Faculdade de Macapá, Macapá, Amapá, Brazil. \\ ${ }^{3}$ Embrapa Clima Temperado, Pelotas, Rio Grande do Sul, Brazil. \\ ${ }^{4}$ Escola Superior de Agricultura "Luiz de Queiroz", Universidade de São Paulo, Piracicaba, \\ São Paulo, Brazil. \\ ${ }^{5}$ Embrapa Amapá, Macapá, Amapá, Brazil.
}

Authors' contributions

This work was carried out in collaboration among all authors. Authors MSMS and JEVS managed the literature searches and wrote the first draft of the manuscript. Authors DEN, RAZ and RA discussed the collected data and wrote the final version. All authors read and approved the final manuscript.

Article Information

DOI: 10.9734/ARRB/2021/v36i930424 Editor(s):

(1) Dr. Saleha Sadeeqa, Lahore College for Women University, Pakistan. Reviewers: (1) Wan Nur Madihah Wan Abd Halim, University College Agroscience Malaysia, Malaysia. (2) Kwaku Achiano, Agricultural Research Council, South Africa. Complete Peer review History: https://www.sdiarticle4.com/review-history/73363

Review Article

Received 05 July 2021 Accepted 15 September 2021 Published 20 September 2021

\begin{abstract}
Fruit-bearing plants in the Brazilian Amazon are mainly attacked by species of Anastrepha, of which about half are endemic to the region. However, tritrophic relations (fly/plant/parasitoid) have only been established for some $25 \%$ of the species of Anastrepha in the region. At present, 11 species of hymenopterous parasitoids (Braconidae and Figitidae) have been recorded in the Brazilian Amazon. Parasitoids in general, especially those of the family Braconidae, stand out as the most effective natural enemies of fruit flies of the genus Anastrepha. Doryctobracon areolatus is the most abundant parasitoid and it is associated with the largest number of Anastrepha species in the region. Some fruiting species, for example Bellucia grossularioides (L.) Triana and
\end{abstract}


Geissospermum argenteum Woodson, have been studied aiming at biological control of fruit flies, because they act as reservoirs or multipliers of fruit fly parasitoids. Although research has advanced significantly in the past 20 years, there is a shortage of studies in nearly all states in the region, due to the huge area of the Brazilian Amazon.

Keywords: Biological control; diversity; parasitism; tritrophic relationships.

\section{INTRODUCTION}

Studies of bio-ecology and the potential of hymenopterous parasitoids for biological control of fruit flies in Brazil have been increasing in recent decades, for four main reasons: (1) clarification on the identity of fruit fly parasitoids [1]; (2) improvement of techniques for mass rearing of exotic parasitoids - Diachasmimorpha longicaudata (Ashmead) and Fopius arisanus (Sonan) - and native species - Doryctobracon areolatus (Szépligeti), Doryctobracon brasiliensis (Szépligeti) and Aganaspis pelleranoi (Brèthes) for control of Anastrepha fraterculus (Wiedemann) and Ceratitis capitata (Wiedemann), principally in the South region of Brazil $[2,3,4,5]$; (3) growing restrictions on application of toxic chemicals for pest control and the increased public awareness of food safety; and (4) effort to preserve biodiversity of agroecosystems, through ecologically friendly strategies, which are aimed at maintaining and increasing the population of natural enemies of pests [6].

In the Brazilian Amazon, braconid parasitoids of fruit flies belong to the subfamilies Alysiinae (Asobara) and Opiinae (Doryctobracon, Opius and Utetes) and the figitids belong to the subfamily Eucoilinae (Aganaspis and Odontosema) [7].

Because of the importance of parasitoids for regulation of fruit fly populations, this review compiles and updates information on the Braconidae and Figitidae, with emphasis on their species richness and geographic distribution in the Brazilian Amazon. The potential of fruitbearing plants as reservoirs or multipliers of parasitoids and research trends for biological control of fruit flies in the Brazilian Amazon were also discussed.

\section{THE BRAZILIAN AMAZON: A CHALLENGE FOR STUDIES OF FRUIT FLIES AND THEIR PARASITOIDS}

The Brazilian Amazon covers the states of Acre, Amapá, Amazonas, Mato Grosso, Pará,
Roraima, Rondônia and Tocantins, and part of Maranhão (to the west of the $44^{\circ}$ meridian) [8], and it corresponds to about $60 \%$ of the total area of Amazon (more than 6.5 million $\mathrm{km}^{2}$ ).

The cultivation of fruit-bearing species in the Amazon has large agro-industrial potential. There are approximately 200 species that bear edible fruits, half of which are native species, the great majority occurring in the wild [9]. This scenario suggests that the Amazon has the potential to become a large supplier of fruits. The utilization of these species, both in natural conditions and under cultivation, is important for the development of sustainable agriculture, bringing various social benefits [10]. Despite the recognition of this potential for fruit production, a major factor limiting commercial-scale production is the presence of pests, mainly fruit flies, a group of insects that cause the greatest damage to global agriculture [11].

Studies on fruit flies in the Brazilian Amazon was incipient until the early 1990s. Since then, significant advances have been achieved, in particular through implementation of the Amazon Network for Research on Fruit Flies (Phase I: 2007-2010 and Phase II: 2011-2014). Great advances have been made regarding scientific knowledge in the past 15 years, especially in the states of Amapá, Pará and Roraima [12]. A compilation of these results were published in the book "Moscas-das-frutas na Amazônia brasileira: diversidade, hospedeiros e inimigos naturais" [7].

In the Brazilian Amazon, 78 species of Anastrepha have been recorded, about half of them are endemic. The most recent compilation of records of fruit flies and their host plants can be found in the database "Anastrepha species and their hosts in the Brazilian Amazon" [13]. Besides of the native species of Anastrepha, two exotic species have been recorded in the region. The first is Bactrocera carambolae Drew \& Hancock, the carambola fruit fly, the only species of the genus in South America. It was first detected in Amapá, Brazil, in 1996 [14]. The second is Ceratitis capitata, the Mediterranean fruit fly, detected in the Amazon region in 1996 
[15]. In the Brazilian Amazon, this pest was not recorded only in the states of Amapá and Amazonas [16,17].

Fruit samplings has been carried out mainly in the states of Amapá and Pará, where there are several available records of fruit flies, their host plants and parasitoids.

\section{FRUIT FLY PARASITOIDS IN THE BRAZILIAN AMAZON}

Studies on fruit fly parasitoids were neglected in the region for many years. The first records were of $D$. areolatus, Opius bellus Gahan, Utetes anastrephae (Viereck) and Asobara anastrephae (Muesebeck), collected in the municipalities of Manaus and Iranduba in Amazonas [18]. However, further research on fruit fly parasitoids were carried out in the following decades. Two species from Brazilian Amazon were described at the end of 2020s. One of these species ( $D$. whartoni Marinho \& Penteado-Dias) is known only in the Amapá state. Information on the parasitized fruit flies, associated host plants, geographical distributions and respective citations are presented in the Checklist.

Eleven species of fruit fly parasitoids have been recorded in Brazilian Amazon, but most species belong to Braconidae (8 species). Doryctobracon areolatus is the most widespread species, having been found in all states of the region, followed by $O$. bellus, that so far has not been recorded in Mato Grosso (Fig 1, Checklist). Some braconids, such as $D$. longicaudata, $F$. arisanus (exotic), $D$. areolatus and $D$. brasiliensis (native) have been used for the biological control of fruit flies [1].

The diversity of figitids that parasitize fruit flies in the Amazon is poorly known, restricted to a few occasional collections in Amazonas, Amapá, Pará and Roraima [19, 20]. The record of Tropideucoila rufipes Ashmead in the state of Amazonas [21], it is a missidentification, as it is actually Trichopria sp. aff. anastrephae (Diapriidae) (Jorge A. Guimarães, personal communication). As this is a single record that requires further studies, this diapriid was not discussed herein.

Studies on fruit flies and their natural enemies are hampered mainly, in the Brazilian Amazon, by the shortage of technicians and the focus of researchers on other groups of economically important insects. Another difficulty is the limited means of access (transportation) to the different ecosystems, since many municipalities cover large areas with limited transportation infrastructure [22]. For example, only two papers have been published on the occurrence of fruit fly parasitoids in Maranhão, the most recent one 20 years ago [23, 24] (Checklist).

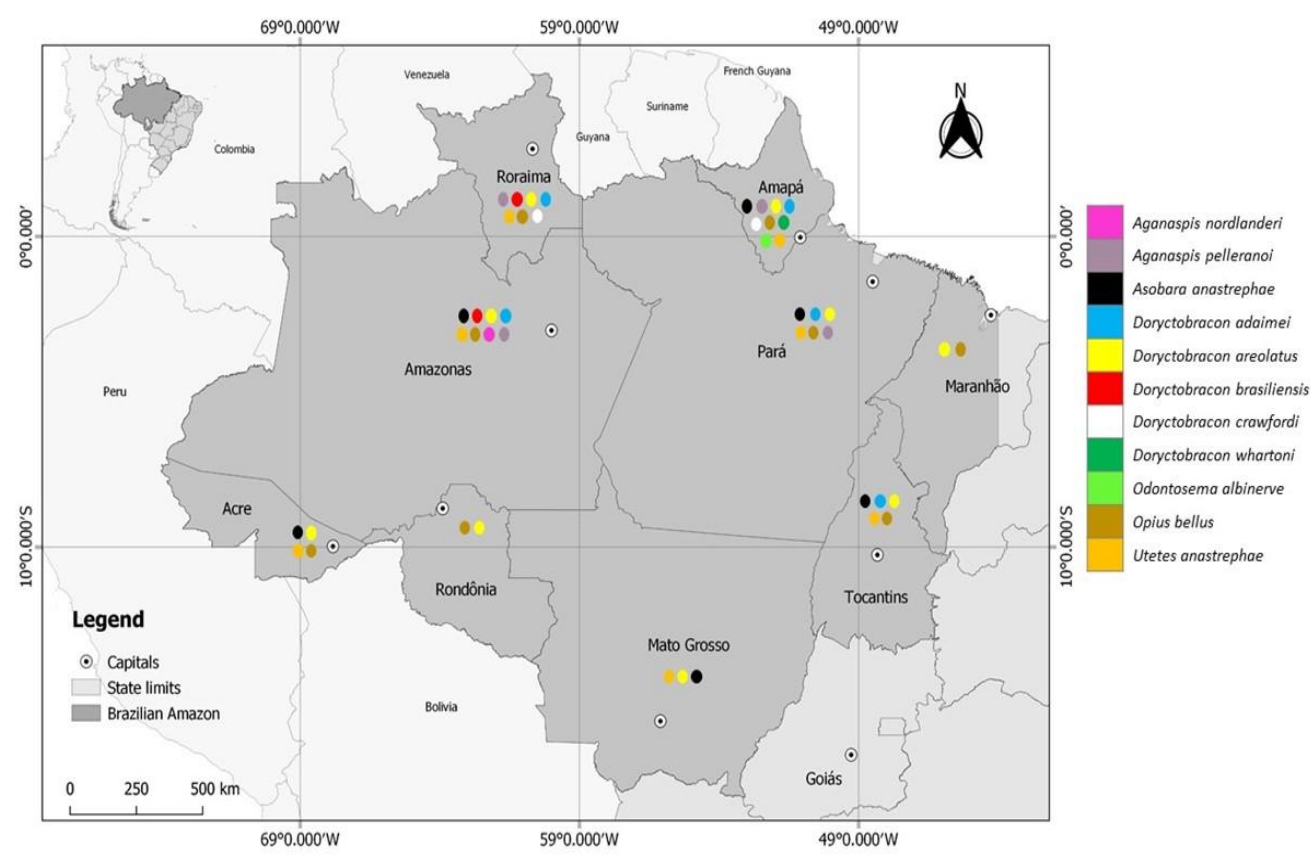

Fig. 1. Distribution of parasitoids of Anastrepha fruit flies in the nine states of the Brazilian Amazon 
These difficulties are most severe in Amazonas, the largest Brazilian state in area, with strong potential for the development of fruit cultivation, but there is no information about the main pests and their natural enemies in this state. The studies in Amazon state have been concentrated in only a few collection sites [25, 26, 27].

\section{TRITROPHIC RELATIONSHIPS}

The relationship among fruit flies, host plants and parasitoids is a key for the establishment of conservation biological control programs. Therefore, fruit sampling from a single species of host plant, should be assessed to determine the level of fruit infestation, in order to correctly establish the association of each fruit fly species and host plant species, and to generate information about the diversity and abundance of natural enemies [28].

Doryctobracon areolatus has been found to parasitize 19 species of Anastrepha on 50 plant species, distributed in 18 botanical families. Opius bellus is associated with 12 species of Anastrepha on 22 host plants belonging to 13 botanical families. Doryctobracon brasiliensis and $D$. whartoni are associated only with Anastrepha fractura Stone and Anastrepha atrigona Hendel, respectively. With regard to figitids, $A$. nordlanderi and A. pelleranoi have been collected mainly in Amazonas and Amapá, where they have been found associated with four and eight species of Anastrepha, respectively (Checklist).

In Mato Grosso state, the first fruit fly collections using food-baited traps were carried out only in 2000 , and several species were recorded [17, $26,29,30]$. The first record of fruit fly parasitoid in the state was $D$. areolatus on $A$. striata in fruit of $P$. cattleianum (Myrtaceae), in the municipality of Sinop (Checklist) [31]. Two years later, $U$. anastrephae and $A$. anastrephae were reported for the first time in the state (Checklist) [17].

'Hosts plants' for fruit fly species and their associated natural enemies are scarce in Acre, Rondônia and Tocantins. In Tocantins, for example, there are only records of parasitism of $A$. anastrephae, $D$. areolatus and $O$. bellus on $A$. obliqua in Mangifera indica and $D$. areolatus and $D$. adaimei (such as Dorycobracon sp.) on $A$. coronilli in Bellucia grossularioides [32].

There are no reports of native parasitoids of the exotic species $B$. carambolae and $C$. capitata in the Brazilian Amazon [7]. Nevertheless, in 2000, two releases of the exotic parasitoid $D$. longicaudata were performed in Amapá aiming to control B. carambolae [33]. After these releases, no specimens of $D$. longicaudata have been recovered in the various surveys carried out in Amapá since 2004. Thus, Fopius arisanus (egg parasitoid) was introduced for biological control of $B$. carambolae $[34,35]$.

\section{CONSERVATION BIOLOGICAL CONTROL OF Anastrepha FRUIT FLIES IN THE BRAZILIAN AMAZON}

Conservation biological control involves the maintenance and increase in the natural enemies of pests that are already present in the environment $[36,37]$. In the Amazon region, this kind of biological control has attracted the attention of researchers in the last two decades, because some wild plant species are important reservoirs or multipliers of fruit fly parasitoids [12].

Spondias mombin L., Bellucia grossularioides (L.) Triana and Geissospermum argenteum Woodson found in the Brazillian Amazon have the potential of been reservoirs of fruit fly parasitoids [12].

Spondias mombin (yellow mombin or hog plum) is a native species exploited mainly via extractivism, with few initiatives for planting in commercial orchards. However, in recent years the commercialization of this fruit has been expanding along with the market for native fruits from the Amazon region. It is considered a parasitoid multiplier plant, with parasitism indices of $50 \%$ of fruit fly puparia $[12,38,39]$. Doryctobracon areolatus and $O$. bellus have been associated with $S$. mombin in five Brazilian Amazon states. In Amapá, five parasitoid species are often found in samples of mombin fruit infested with Anastrepha spp. (Checklist). Spondias mombin fruit is frequently collected in the Amazon region. The highest parasitism recorded for this host plant species was $52.7 \%$ in fruits sampled in the state of Pará (Table 1).

Bellucia grossularioides grows in areas with both altered and unaltered vegetation. It has high capacity to adapt to a wide range of soil types. It is among the most important pioneer species in terms of number of individuals per area in the Central Amazon. It produces flowers and fruits for long periods or continuously throughout the year $[40,41]$. In a study conducted in several states in the Brazilian Amazon, parasitism rates of up to $28 \%$ of fruit fly puparia were recorded (Table 1). Seven parasitoid species have been associated with $B$. grossularioides, of which 
$D$. areolatus was predominant $[42$, Checklist and Table 1].

Geissospermum argenteum, known in Amapá as "quina" [12], is frequently used by traditional communities for the treatment of malaria [43,44]. In a recent study carried out in a fragment of upland forest in the south of the state of Amapá, the potential of this plant species as a reservoir for fruit fly parasitoids was evaluated [45]. The estimates showed a positive linear relationship between fruit production of $G$. argenteum, density of fruit flies and parasitoids, that is, the greater the fruit production, the greater the quantity of fruit flies and parasitoids. The average density of parasitoids per $\mathrm{kg}$ of fruit (3.52) and per tree (38.9) were relatively low. However, this corresponded to about 2,500 parasitoids per ha. In this reservoir plant, parasitism is generally less than $10 \%$, but this is compensated by the high rate of infestation by fruit flies of no economic importance and by the diversity of associated generalist parasitoids (Checklist).

Some plant species with fruit fly parasitism has been found be greater than $10 \%$ (Table 1). It is not possible to present the percentages for the states of Maranhão, Mato Grosso and Tocantins, because data published, such as, quantity of fruits sampled, number of puparia and number of parasitoids in each sample, were not evaluated.

Loreya mespiloides Miq. and Bellucia egensis (Mart. Ex DC.) Penneys, FA Michelangeli, Judd \& Almeda have presented significant parasitism percentages of fruit fly by braconids. In samples of $L$. mespiloides from municipality of Amajari, Roraima state, the fruit fly parasitism by $D$. adaimei was $62.3 \%$. In B. egensis, the highest parasitism rate reached $42.9 \%$ (Table 1). These host plants have high potential as reservoirs of fruit fly parasitoids and should be better studied aiming their use for biological control of economically important fruit flies in the Amazon region.

\section{CHECKLIST OF PARASITOIDS OF Anastrepha FRUIT FLIES AND ASSOCIATED PLANTS IN THE BRAZILIAN AMAZON}

\subsection{Figitidae}

\subsubsection{Aganaspis nordlanderi Wharton}

Distribution. Amazonas: Manaus [46], Presidente Figueiredo [47].
Hosts. A. antunesi ex Spondias mombin [47], A. coronilli ex Bellucia grossularioides [46], A. fractura ex Maquira sclerophylla [48], A. striata ex Psidium guajava [21].

\subsubsection{Aganaspis pelleranoi (Brèthes)}

Distribution. Amazonas: Manaus [46], Presidente Figueiredo [47]. Amapá: Ferreira Gomes and Serra do Navio [49], Macapá, Mazagão, Porto Grande, and Santana [50], Oiapoque [33], Pedra Branca do Amapari [51], Tartarugalzinho [52]. Pará: Afuá and Melgaço [53], Altamira [54]. Roraima: Amajari [55], Boa Vista [56].

Hosts. A. antunesi ex Spondias mombin [47], $A$. atrigona ex Pouteria durlandii [46], A. bahiensis ex Brosimum potabile [52], A. coronilli ex Bellucia grossularioides [47,49], A. fractura ex Maquira sclerophylla [48], A. obliqua ex Spondias mombin [49, 56], A. obliqua ex Eugenia patrisii [46], A. obliqua ex Averrhoa carambola [54], A. striata ex Psidium guajava [33, 47], A. striata ex Spondias mombin [33], A. turpiniae ex Psidium guajava [47].

\subsection{Braconidae}

\subsubsection{Asobara anastrephae (Muesebeck)}

Distribution. Acre: Rio Branco [57]. Amazonas: Manaus [58], Novo Airão [26], Presidente Figueiredo [47]. Amapá: Itaubal do Piririm [59], Laranjal do Jari and Vitória do Jari [28], Macapá [60], Mazagão [61], Oiapoque [33], Pedra Branca do Amapari and Serra do Navio [51], Porto Grande and Pracuúba [49], Santana [62]. Mato Grosso: Nova Guarita [17]. Pará: Altamira [54], Belém [63], Castanhal [64], Igarapé-Açu and São Francisco do Pará [65], Tomé-Açu [66]. Tocantins: Brejinho de Nazaré, Monte do Carmo, Palmas, and Porto Nacional [32].

Hosts. A. antunesi ex Spondias mombin [47], A. atrigona ex Geissospermum argenteum [51], $A$. bahiensis ex Ampelocera edentula [48], $A$. bahiensis ex Pouroma cecropiaefolia [47], A. coronilli ex Bellucia grossularioides [51], $A$. fractura ex Salacia sp. [47], A. fraterculus ex Chrysobalanus icaco [49], $A$. obliqua ex Spondias mombin [18, 57, 62, 65], A. obliqua ex Averrhoa carambola [54, 65], A. obliqua ex Malpighia glabra [66], A. obliqua ex Malpighia punicifolia [67], A. obliqua ex Mangifera indica [32], A. striata ex Psidium guajava [33], A. striata ex Spondias mombin [33]. 
Table 1. Percentage of Anastrepha parasitism on fruit flies infesting several plant species in the Brazilian Amazon

\begin{tabular}{|c|c|c|c|c|c|c|c|}
\hline States & Plant species & Mass(kg) & Puparia (n) & Infestation (puparia/kg) & Parasitoid species & Parasitism (\%) & References \\
\hline \multirow[t]{2}{*}{ Acre } & Bellucia grossularioides & 0.6 & 49 & 81.7 & Doryctobracon areolatus & 10.2 & [71] \\
\hline & Spondias mombin & 2.4 & 468 & 195.0 & $\begin{array}{l}\text { Doryctobracon areolatus } \\
\text { Opius bellus } \\
\text { Utetes anastrephae }\end{array}$ & 29.5 & [70] \\
\hline \multirow[t]{3}{*}{ Amapá } & Bellucia egensis & 0.25 & 35 & 139.5 & Doryctobracon areolatus & 42.9 & [91] \\
\hline & Bellucia grossularioides & 0.79 & 175 & 220.9 & $\begin{array}{l}\text { Doryctobracon areolatus } \\
\text { Aganaspis pelleranoi }\end{array}$ & 28.0 & [49] \\
\hline & Spondias mombin & 2.3 & 149 & 64.7 & $\begin{array}{l}\text { Doryctobracon areolatus } \\
\text { Opius bellus }\end{array}$ & 46.9 & [49] \\
\hline \multirow[t]{4}{*}{ Amazonas } & Malpighia glabra & 1.3 & 79 & 60.7 & $\begin{array}{l}\text { Doryctobracon areolatus } \\
\text { Opius bellus }\end{array}$ & 41.7 & [47] \\
\hline & Manihot esculenta & 2.2 & 393 & 178.6 & $\begin{array}{l}\text { Doryctobracon areolatus } \\
\text { Opius bellus }\end{array}$ & 34.1 & [47] \\
\hline & & & & & Utetes anastrephae & & \\
\hline & Spondias mombin & 3.1 & 586 & 189.0 & $\begin{array}{l}\text { Asobara anastrephae } \\
\text { Doryctobracon areolatus } \\
\text { Opius bellus } \\
\text { Utetes anastrephae } \\
\text { Aganaspis nordlanderi } \\
\text { Aganaspis pelleranoi }\end{array}$ & 30.0 & [47] \\
\hline \multirow[t]{2}{*}{ Pará } & Malpighia emarginata & 1.27 & 150 & 118.1 & $\begin{array}{l}\text { Doryctobracon areolatus } \\
\text { Opius bellus } \\
\text { Utetes anastrephae }\end{array}$ & 30.7 & [63] \\
\hline & Spondias mombin & 1.20 & 560 & 466.7 & $\begin{array}{l}\text { Doryctobracon areolatus } \\
\text { Opius bellus }\end{array}$ & 52.7 & [63] \\
\hline Rondônia & Averrhoa carambola & 2.2 & 45 & 20.5 & $\begin{array}{l}\text { Doryctobracon areolatus } \\
\text { Opius bellus }\end{array}$ & 22.0 & [71] \\
\hline \multirow[t]{3}{*}{ Roraima } & Loreya mespiloides & 0.68 & 122 & 178.6 & $\begin{array}{l}\text { Doryctobracon areolatus } \\
\text { Doryctobracon adaimei }\end{array}$ & 62.3 & [55] \\
\hline & Manihot esculenta & 1.19 & 133 & 111.8 & Doryctobracon areolatus & 38.3 & [56] \\
\hline & Spondias purpurea & 1.84 & 119 & 64.7 & $\begin{array}{l}\text { Doryctobracon areolatus } \\
\text { Opius bellus } \\
\text { Utetes anastrephae }\end{array}$ & 46.2 & [56] \\
\hline
\end{tabular}




\subsubsection{Doryctobracon adaimei Marinho \& Penteado-Dias}

Distribution. Amazonas: Presidente Figueiredo [47]. Amapá: Calçoene and Oiapoque [68], Laranjal do Jari and Vitória do Jari [28], Pedra Branca do Amapari and Serra do Navio [51], Porto Grande [60], Tartarugalzinho [69]. Pará: Belém [63]. Roraima: Amajari [55]. Tocantins: Palmas [32].

Hosts. A. atrigona ex Geissospermum argenteum [51], A. coronilli ex Bellucia grossularioides [32, 42], A. coronilli ex Loreya mespiloides [55], A. striata ex Psidium guajava [28, 47], A. striata ex Psidium araca [63].

\subsubsection{Doryctobracon areolatus (Szépligeti)}

Distribution. Acre: Bujari and Rio Branco [70], Capixaba [71]. Amazonas: Barcelos, Rio Preto da Eva, and Tefé [26], Manaus [58], Presidente Figueiredo [47]. Amapá: Amapá, Cutias do Araguari, Ferreira Gomes, Itaubal do Piririm, Macapá, Mazagão, Porto Grande, Serra do Navio, and Vitória do Jari [72], Calçoene [73], Laranjal do Jari [28], Oiapoque [26], Pedra Branca do Amapari [51], Pracuúba [42], Santana [60], Tartarugalzinho [69]. Maranhão: Santa Inês [24], São Luís [23]. Mato Grosso: Nova Guarita [17], Sinop [31]. Pará: Afuá [74], Altamira [54], Belém [75], Belterra, Breves, Gurupá, Melgaço, and Santarém [53], Capitão Poço [76], Castanhal, Igarapé-Açu, and São Francisco do Pará [65], Tomé-Açu [66]. Rondônia: Ouro Preto do Oeste [71], Porto Velho [47]. Roraima: Amajari [55], Boa Vista and Pacaraima [26], Bonfim and Cantá [56], Normandia [77]. Tocantins: Palmas and Porto Nacional [32].

Hosts. A. amita ex Citharexylum poeppigii [55], A. antunesi ex Spondias mombin [47, 78], A. atrigona ex Geissospermum argenteum [51], A. bahiensis ex Ampelocera edentula [48], $A$. bahiensis ex Helicostylis scabra [79], A. bahiensis ex Helicostylis tomentosa [46], A. bahiensis ex Pouroma cecropiaefolia [47], A. coronilli ex Bellucia grossularioides [32, 46, 51, 56, 71], A. coronilli ex Bellucia dichotoma [48], A. coronilli ex Loreya mespiloides [55], A. distincta ex Inga edulis [28, 65, 80], A. distincta ex Inga laurina [49], $A$. fraterculus ex Terminalia catappa [18], A. fraterculus ex Psidium guajava [78], A. fractura ex Maquira sclerophylla [48], A. fractura ex Salacia sp. [47], A. leptozona ex Pouteria caimito [47, 49], A. manihoti ex Manihot esculenta [55], A. obliqua ex Anacardium occidentale [47], A. obliqua ex Averrhoa carambola [47, 54, 71], A. obliqua ex Eugenia stipitata [81], A. obliqua ex Eugenia uniflora [65, 82], A. obliqua ex Malpighia emarginata [65, 83, 84], A. obliqua ex Malpighia glabra [47, 66], A. obliqua ex Malpighia punicifolia [75, 77], $A$. obliqua ex Mangifera indica [32, 47], A. obliqua ex Myrciaria dubia [18], A. obliqua ex Psidium acutangulum [80], A. obliqua ex Psidium guajava [70], A. obliqua ex Spondias mombin [47, 56, 60, 64, 70], A. obliqua ex Spondias purpurea [56], A. obliqua ex Syzygium jambos [65], A. pickeli ex Manihot esculenta [47], A. pseudanomala ex Couma utilis [85], A. pulchra ex Pouteria oblanceolata [86], A. serpentina ex Citrus sinensis [76, 87], A. serpentina ex Manilkara huberi [28], A. serpentina ex Manilkara zapota [67], A. serpentina ex Pouteria caimito [47, 64, 80], A. serpentina ex Pouteria gardneri [88], A. striata ex Artocarpus heterophyllus [89], A. striata ex Pouteria caimito [33], A. striata ex Psidium acutangulum [80], A. striata ex Psidium cattleianum [31], A. striata ex Psidium guajava $[17,21,33,84,90]$, A. striata ex Psidium guineense [56, 71], A. striata ex Spondias mombin [33], A. striata ex Syzygium malaccense [73], A. turpiniae ex Spondias mombin [72], A. turpiniae ex Terminalia catappa [47], A. zacharyi ex Bellucia egensis [91], A. zenildae ex Psidium guajava [88], A. zenildae ex Ziziphus mauritiana [92].

\subsubsection{Doryctobracon brasiliensis (Szépligeti)}

Distribution. Amazonas: Manaus [26]. Roraima: Boa Vista and Pacaraima [26].

Hosts. A. fractura ex Salacia sp. [47].

\subsubsection{Doryctobracon crawfordi (Viereck)}

Distribution. Amapá: Laranjal do Jari [28], Porto Grande [49]. Roraima: Amajari [93], Pacaraima [56].

Hosts. A. atrigona ex Geissospermum argenteum [28], A. coronilli ex Bellucia grossularioides [49], A. serpentina ex Pouteria caimito [56].

\subsubsection{Doryctobracon whartoni Marinho \& Penteado-Dias}

Distribution. Amapá: Pedra Branca do Amapari [51].

Hosts. A. atrigona ex Geissospermum argenteum [51] 


\subsubsection{Odontosema albinerve Kieffer}

Distribution. Amapá: Porto Grande [50].

\subsubsection{Opius bellus Gahan}

Distribution. Acre: Bujari [70]. Amazonas: Manaus [58], Presidente Figueiredo [47]. Amapá: Calçoene [73], Ferreira Gomes [94], Laranjal do Jari [28], Macapá, Mazagão, and Santana [60], Oiapoque [72], Pedra Branca do Amapari and Serra do Navio [51], Porto Grande [49], Tartarugalzinho and Vitória do Jari [42]. Maranhão: Caxias and Santa Inês [24]. Pará: Afuá, Breves, Gurupá, and Melgaço [53], Altamira [54], Belém [75], Castanhal, IgarapéAçu, and São Francisco do Pará [65], Tomé-Açu [66]. Rondônia: Ouro Preto do Oeste [71]. Roraima: Amajari [55], Boa Vista [90], Bonfim, Cantá, Normandia, and Pacaraima [56]. Tocantins: Araguatins [95], Brejinho de Nazaré and Porto Nacional [32].

Hosts. A. antunesi ex Spondias mombin [96], A. atrigona ex Geissospermum argenteum [51], $A$. atrigona ex Pouteria durlandii [46], A. bahiensis ex Pouroma cecropiaefolia [47], A. coronilli ex Bellucia grossularioides [47, 73], A. fractura ex Salacia sp. [47], A. fraterculus ex Psidium guajava [78], A. hastata ex Cheiloclinium cognatum [97], A. manihoti ex Manihot esculenta [47, 55], A. obliqua ex Averrhoa carambola [54, 71], A. obliqua ex Eugenia stipitata [81, 90], A. obliqua ex Eugenia uniflora [82, 90], A. obliqua ex Malpighia emarginata [65], A. obliqua ex Malpighia glabra [47, 66], A. obliqua ex Malpighia punicifolia [67, 75], A. obliqua ex Spondias mombin [47, 60, 65, 70, 90], A. obliqua ex Spondias purpurea [90], A. obliqua ex Syzygium jambos [65], A. striata ex Psidium guineense [71], A. striata ex Spondias mombin [78], A. turpiniae ex Spondias mombin [72], A. zenildae ex Psidium guajava [88].

\subsubsection{Utetes anastrephae (Viereck)}

Distribution. Acre: Bujari [70]. Amazonas: Manaus [26], Presidente Figueiredo [47]. Amapá: Calçoene [73], Ferreira Gomes [94]), Laranjal do Jari [28], Macapá and Santana [60], Mazagão [99], Oiapoque [33], Porto Grande [72], Serra do Navio [51]. Mato Grosso: Nova Guarita and Sinop [17]. Pará: Altamira [54], Belém [75], Tomé-Açu [66]. Roraima: Amajari [55], Bonfim [77], Normandia and Pacaraima [56]. Tocantins: Araguatins [95], Brejinho de Nazaré [32].

Hosts. A. antunesi ex Spondias mombin [47, 78], A. bahiensis ex Ampelocera edentula [48], A. coronilli ex Bellucia grossularioides [47], A. manihoti ex Manihot esculenta [18], A. obliqua ex Averrhoa carambola [54], A. obliqua ex Malpighia glabra [66], A. obliqua ex Malpighia punicifolia [67, 75], A. obliqua ex Mangifera indica [18], A. obliqua ex Spondias mombin [47, 49, 56, 70], $A$. obliqua ex Spondias purpurea [17, 56], A. pickeli ex Manihot esculenta [47], A. striata ex Psidium guajava [33], A. striata ex Spondias mombin [33,78], A. turpiniae ex Spondias mombin [72].

\section{CONCLUSION}

The Brazilian Amazon is undoubtedly endowed with rich biodiversity, including many species of parasitoids that can act in the biological control of fruit flies, but have not yet been widely studied or identified. The vast geographic expanse of the region, with remote sites having difficult access, poses a challenge to the scientific community. Additionally, the scarcity of qualified human resources for conducting bio-ecological studies of fruit flies represents another constraint.

It is crucial for studies to sample fruit-bearing plants, although relatively expensive, to be performed in all states of the Brazilian Amazon, to increase knowledge of the richness of the fruit fly parasitoid species and their geographic distribution. The priority areas are the states of Acre, Maranhão, Mato Grosso, Rondônia and Tocantins, which so far have been mostly neglected in studies of this type. Additionally, studies should be prioritized using individual fruit method [22], which although laborious, is very useful to understand the tritrophic relationship involving species of fruit fly, their host fruit and parasitoid.

It is also necessary to establish or adapt methods for laboratory rearing of some parasitoid species that occur in the region, to facilitate biological studies of these species. In this regard, there is a particular need to study $D$. adaimei and $D$. whartoni, parasitoids recently described from specimens collected in the Brazilian Amazon, whose biological parameters are not known. The use of these parasitoids could help support biological control programs, which are essential to control fruit flies according to management strategies over large areas by combining sterile insect technique and application of toxic bait.

Studies seeking to increase conservation biological control of fruit flies should be encouraged. It is essential to investigate the potential of wild plant species which could be 
reservoirs or multipliers of parasitoids. Some of these species are already being studied, such as $B$. grossulariodes, G. argenteum and S. mombin, which augurs well for the biological control of fruit flies in Brazil and scientific community at large.

\section{ACKNOWLEDGEMENTS}

To the National Council for Scientific and Technological Development - CNPq, for the Research Productivity Fellowship granted to Ricardo Adaime, Dori E. Nava and to Roberto A. Zucchi, and the Doctoral Scholarship granted to Maria do Socorro Miranda de Sousa.

\section{COMPETING INTERESTS}

Authors have declared that no competing interests exist.

\section{REFERENCES}

1. Marinho CF, Costa VA, Zucchi RA. Annotated checklist and illustrated key to braconid parasitoids (Hymenoptera, Braconidae) of economically important fruit flies (Diptera, Tephritidae) in Brazil. Zootaxa. 2018; 4527(1):021-036.

DOI: https://doi.org/10.11646/zootaxa.4527.1.2

2. Nava DE, Botton M. Bioecologia e controle de Anastrepha fraterculus e Ceratitis capitata em pessegueiro. Embrapa Clima Temperado, Pelotas. 2010;315.

3. Gonçalves RS, Andreazza F, Lisbôa H, Grützmacher AD, Valgas RA, ManicaBerto R, Nörnberg SD, Nava DE. Basis for the development of a rearing technique of Aganaspis pelleranoi (Hymenoptera: Figitidae) in Anastrepha fraterculus (Tephritidae: Diptera). J. Econ. Entomol. 2016;109(3):1094-1101.

Doi: $10.1093 /$ jee/tow069.

4. Gonçalves RS, Nunes AM, Poncio S, Manica-Berto R, Nornberg SD, Grutzmacher AD, Nava DE. Bionomics, thermal requirements and life table of the fruit fly parasitoid Doryctobracon areolatus (Hymenoptera: Braconidae) under various thermal regimes. Biol. Control. 2018; 127:101-108.

DOI: 10.1016/j.biocontrol.2018.08.025

5. Poncio S, Nunes AM, Gonçalves RS, Lisboa $H$, Manica-Berto R, Garcia MS, Nava DE. Strategies for establishing a rearing technique for the fruit fly parasitoid: Doryctobracon brasiliensis (Hymenoptera:
Braconidae). J. Econ. Entomol. 2018;111(3):1087-1095.

DOI: https://doi.org/10.1093/jee/toy058

6. Paranhos BJ, Nava DE, Malavasi A. Biological control of fruit flies in Brazil. Pesqui. Agropecu. Bras. 2019; 54:1-14. DOI: $\quad$ https://doi.org/10.1590/S16783921.pab2019.v54.26037

7. Silva RA, Lemos WP, Zucchi RA, editores. Moscas-das-frutas na Amazônia brasileira: diversidade, hospedeiros e inimigos naturais. 1a ed. Amapá: Embrapa; 2011.

8. IBGE. Amazônia Legal;2019. Accessed June 19, 2020.

Available:https://www.ibge.gov.br/geocienc ias/cartas-e-mapas/mapas-regionais

9. Cavalcante PB, editor. Frutas comestíveis na Amazônia. 70 ed. Pará: Museu Paraense Emílio Goeldi; 2010.

10. Souza AGC, Silva SEL. Frutas nativas da Amazônia. In: 20을 Congresso Brasileiro de Fruticultura, 54ㅇ Annual Meeting of the Interamerican Society for Tropical Agriculture, Vitória, Espirito Santo; 2008.

11. Aluja M, Mangan RL. Fruit fly (Diptera: Tephritidae) host status determination: critical conceptual, methodological, and regulatory considerations. Annu. Rev. Entomol. 2008;53:473-502.

DOI:https://doi.org/10.1146/annurev.ento.5 3.103106.093350

12. Adaime R, Lima AL, Sousa MSM. Controle biológico conservativo de moscas-dasfrutas na Amazônia brasileira. Innov. agron. 2018;64:47-59.

13. Adaime R, Sousa MSM, Pereira JF. Anastrepha species and their host in the Brazilian Amazon. 2016.

Accessed 15 May 2020.Available: http://anastrepha.cpafap.embrapa.br

14. Silva OLR, Suman R, Silva JR. Mosca da carambola (Bactrocera carambolae Drew \& Hancock). Brasília: Ministério da Agricultura e do Abastecimento, Alerta Quarentenário. 1997;1.

15. Ronchi-Teles B, Silva NM. Primeiro registro de ocorrência da mosca-domediterrâneo, Ceratitis capitata (Wied.) (Diptera: Tephritidae) na Amazônia Brasileira. An. Soc. Entomol. Brasil. 1996; 25(3):569-570.

DOI: $\quad$ https://doi.org/10.37486/03018059.v25i3.1179

16. Castilho AP, Brandão CAC, Ayres AR, Pereira JF, Adaime R. Distribuição geográfica e plantas hospedeiras de 
Ceratitis capitata (Wiedemann) (Diptera: Tephritidae) na Amazônia brasileira. In: Jasper M, editor. Coletânea Nacional Sobre Entomologia. Paraná: Atena; 2019.

17. Silva MES, Wochner MA, Sousa MSM, Barreto MR, Adaime R. Moscas-das-frutas (Diptera: Tephritidae), suas plantas hospedeiras e parasitoides (Hymenoptera: Braconidae) no norte do estado do Mato Grosso, Brasil. Nativa. 2019; 7(5):513-519. DOI: 10.31413/nativa.v7i5.7461

18. Canal NAD, Zucchi RA, Silva NM, SilveiraNeto $S$. Análise faunística dos parasitóides (Hymenoptera, Braconidae) de Anastrepha spp. (Diptera, Tephritidae) em Manaus e Iranduba, Estado do Amazonas. Acta Amaz. 1995; 25(3-4).

DOI: $\quad$ https://doi.org/10.1590/180943921995253246

19. Guimarães JA, Zucchi RA. Chave de identificação de Figitidae (Eucoilinae) parasitoides de larvas frugívoras na região Amazônica. In: Silva RA, Lemos WP, Zucchi RA, editores. Moscas-das-frutas na Amazônia brasileira: diversidade, hospedeiros e inimigos naturais. 1a ed. Amapá: Embrapa; 2011.

20. Sousa MSM, Adaime R, Pereira JF. Fruit fly parasitoids in the Brazilian Amazon;2016.

Accessed 12 May 2020.Available: http://parasitoid.cpafap.embrapa.br

21. Silva NM, Silva FCC, Cruz DS. Ocorrência de parasitoides de Anastrepha striata (Diptera: Tephritidae) no estado do Amazonas. In: 14 Simpósio de Controle Biológico, Teresópolis, Rio de Janeiro;2015.

22. Silva RA, Deus EG, Raga A, Pereira JDB, Souza Filho MF, Costa Neto SV. Monitoramento de moscas-das-frutas na Amazônia: amostragem de frutos e uso de armadilhas. In: Silva RA, Lemos WP, Zucchi RA, editores. Moscas-das-frutas na Amazônia brasileira: diversidade, hospedeiros e inimigos naturais. 1a ed. Amapá: Embrapa; 2011.

23. Leonel Junior FL, Zucchi RA, Wharton RA. Distribution and tephritid hosts (Diptera) of braconid parasitoids (Hymenoptera) in Brazil. Int. J. Pest Manag. 1995;41(4):208213.

DOI: 10.1080/09670879509371951

24. Oliveira FL, Araujo EL, Chagas EF, Zucchi RA. Maranhão. In: Malavasi A, Zucchi RA, editors. Moscas-das-frutas de importância econômica no Brasil: conhecimento básico e aplicado. São Paulo: Holos; 2000.

25. Silva NM. Levantamento e análise faunística de moscas-das-frutas (Diptera: Tephritidae) em quatro locais do estado do Amazonas. Doctoral Thesis, Universidade de São Paulo, Piracicaba, São Paulo;1993.

26. Ronchi-Teles B. Ocorrência e flutuação populacional de espécies de moscas-dasfrutas e parasitóides com ênfase para o gênero Anastrepha (Diptera: Tephritidae) na Amazônia Brasileira. Doctoral Thesis, Instituto Nacional de Pesquisas da Amazônia / Universidade Federal do Amazonas, Manaus, Amazonas; 2000.

27. Deus EG, Silva RA, Ronchi-Teles B, Zucchi RA. Conhecimento sobre moscasdas-frutas no Estado do Amazonas. In: Silva RA, Lemos WP, Zucchi RA, editores. Moscas-das-frutas na Amazônia brasileira: diversidade, hospedeiros e inimigos naturais. $1 \underline{a}$ ed. Amapá: Embrapa; 2011.

28. Silva RA, Lima AL, Xavier SLO, Silva WR, Marinho CF, Zucchi RA. Anastrepha species (Diptera: Tephritidae), their hosts and parasitoids in southern Amapá State, Brazil. Biota Neotrop. 2011; 11(3):431-436. DOI: $\quad$ https://doi.org/10.1590/S167606032011000300037

29. Uchoa MA, Zucchi RA. Moscas-das-Frutas nos Estados Brasileiros. Mato Grosso e Mato Grosso do Sul. In: Malavasi A, Zucchi RA, editores. Moscas-das-frutas de importância econômica no Brasil: conhecimento básico e aplicado. São Paulo: Holos; 2000.

30. Pontes AV. Biodiversidade de moscas frugívoras (Diptera: Tephritoidea) amostradas com armadilhas McPhail no sudeste de Mato Grosso, Brasil. Master's Dissertation, Universidade Federal da Grande Dourados, Dourados, Mato Grosso do Sul; 2006.

31. Souza MSM, Silva RA, Barreto MR, Wochner MA, Silva MES. Primeiro registro de parasitismo de Anastrepha striata Schiner (Diptera: Tephritidae) na região norte de Mato Grosso. In: 15 Simpósio de Controle Biológico, Ribeirão Preto, São Paulo;2017.

32. Bomfim DA, Uchôa-Fernandes MA, Bragança MAL. Hosts and Parasitoids of Fruit Flies (Diptera: Tephritoidea) in the 
State of Tocantins, Brazil. Neotrop. Entomol. 2007;36(6):984-986.

DOI: $\quad$ https://doi.org/10.1590/S1519566X2007000600025

33. Carvalho RS. Estudos de laboratório e de campo com o parasitóide exótico Diachasmimorpha longicaudata Ashmead (Hymenoptera: Braconidae) no Brasil. Doctoral Thesis, Universidade de São Paulo, São Paulo;2003.

34. Adaime R. Parasitoides no controle biológico de Tefritídeos na Amazônia brasileira. In: 26o Congresso Brasileiro de Entomologia; 9o Congresso Latinoamericano de Entomologia, Maceió, Alagoas; 2016.

35. Lima $A L$, Jesus-Barros $C R$, Bariani $A$, Almeida RP, Adaime R. Potencial de uso de Fopius arisanus (Sonan) (Hymenoptera: Braconidae) para 0 controle de Bactrocera carambolae Drew \& Hancock (Diptera: Tephritidae) no Brasil. In: 15o Simpósio de controle biológico, Ribeirão Preto, São Paulo;2017.

36. Hoy MA. Biological control of arthropod pests: traditional and emerging technologies. Am. J. Agric. Economic 1988; 3(2-3):63-68.

DOI:https://doi.org/10.1017/S08891893000 02198

37. Nordlund DA. Biological control, integrated pest management and conceptual models. Biocontrol News \& Info. 1996;17(2):35-44.

38. Sacramento CK, Souza FX. Cajá. In: Santos-Serejo JLD, Sampaio CV, Coelho YS, editores. Fruticultura tropical: espécies regionais e exóticas. Brasília: Embrapa Informação Tecnológica; 2009.

39. Deus EG, Sousa MSM, Adaime R. Taperebá. In: Silva NM, Adaime R, Zucchi RA, editors. Pragas agrícolas e florestais na Amazônia, 1a ed. Brasília: Embrapa; 2016.

40. Bentos TV, Mesquita RCG, Williamson GB. Reproductive phenology of Central Amazon pioneer trees. Trop. Conserv. Sci. 2008; 1:186-203.

DOI:https://doi.org/10.1177/194008290800 100303

41. Santos GGA, Santos BA, Nascimento HEM, Tabarelli M. Contrasting demographic structure of short- and longlived pioneer tree species on Amazonian forest edges. Biotropica. 2012; 44(6):771778.

DOI: $\quad$ https://doi.org/10.1111/j.17447429.2012.00882.x
42. Adaime R, Sousa MSM, Santos JCR, Deus EG. Pioneer tree species as fruit flies parasitoids reservoir in the Brazilian Amazon. Biota Neotrop. 2018; 18(2):18.

DOI: 10.1590/1676-0611-bn-2017-0428

43. DeFilipps RA, Maina SL, Crepin J. Medicinal plants of the Guianas (Guiana, Surinam, French Guiana). 2004.

Accessed 18 July 2020.Available: http://botany.si.edu/bdg/medicinal/Medicin al_plants_master.pdf

44. Sousa MSM, Baia D, Deus EG, Adaime R, Cunha AC. Índices de infestação de Geissospermum argenteum Woodson (Apocynaceae) por Anastrepha atrigona Hendel (Diptera: Tephritidae) em Laranjal do Jari, Amapá. In: $1^{\text {st }}$ International Symposium, $5^{\text {th }}$ Meeting of the PostGraduate Program in Tropical Biodiversity, Macapá, Amapá;2014.

45. Sousa MSM, Santos JEV, Toledo JJ, Nava DE, Adaime R. Geissospermum argenteum (Angiosperma: Apocynaceae): a reservoir of parasitoids of fruit flies (Diptera: Tephritidae) in an upland forest in the Brazilian Amazon. Agric. For. Entomol. 2021.

DOI: 10.1111/afe.12432.

46. Tregue-Costa AP. Biodiversidade de espécies de Anastrepha spp. Schiner, 1868 (Diptera: Tephritidae) e seus parasitoides na Reserva Florestal Adolpho Ducke, Manaus, Amazonas, Brasil. Master's Dissertation, Instituto Nacional de Pesquisas da Amazônia/Universidade Federal do Amazonas, Manaus, Amazonas;2004.

47. Dutra VS, Ronchi-Teles B, Garcia MVB, Adaime R, Silva JG. Native hosts and parasitoids associated with Anastrepha fracture and other Anastrepha species (Diptera: Tephritidae) in the Brazilian Amazon. Fla Entomol. 2013; 96(1):270273.

DOI: https://www.jstor.org/stable/23608909

48. Costa SGM, Querino RB, Ronchi-Teles B,

Hairstyle-Days AMM, Zucchi RA. Parasitoid diversity (Hymenoptera: Braconidae and Figitidae) on frugivorous larvae (Diptera: Tephritidae and Lonchaeidae) at Adolpho Ducke Forest Reserve, Central Amazon Region, Manaus, Brazil. Braz. J. Biol. 2009; 69:363-370.

49. Deus EG, Pinheiro LS, Lima CR, Sousa MSM, Guimarães JA, Strikis PC, Adaime 
R. Wild hosts of frugivorous dipteran (Tephritidae and Lonchaeidae) and associated parasitoids in the Brazilian Amazon. Fla Entomol. 2013;96:16211625.

50. Silva RA, Pereira JDB, Lemos LN, Silva WR. Espécies de Anastrepha associadas a frutíferas de expressão socioeconômica no Estado do Amapá, Brasil. Rev. Agricul. 2010; 85:207-217.

51. Deus EG, Silva RA, Nascimento DB, Marinho CF, Zucchi RA. Hospedeiros e parasitoides de espécies de Anastrepha (Diptera, Tephritidae) em dois municípios do Estado do Amapá. Rev. Agricul. 2009; 84:194-203.

52. Silva RA, Silva WR, Lima CR, Costa-Neto SV, Souza-Filho MF, Guimarães JA, Zucchi RA. Novo registro de hospedeiro de Anastrepha bahiensis Lima (Diptera: Tephritidae) no Brasil e parasitóide associado. O Biológico, 2009.

53. Pereira JDB. Contribuição ao conhecimento de moscas-das-frutas (Tephritidae e Lonchaeidae) no Pará: diversidade, hospedeiros e parasitóides associados. Master's Dissertation, Universidade Federal do Amapá, Macapá, Amapá, 2009.

54. Santos AO. Parasitóides (Hymenoptera: Braconidae) de moscas-das-frutas (Diptera: Tephritidae) em frutos de caramboleira (Averrhoa carambola L.) no campus Universitário da UFPA em Altamira - PA. Course Completion Paper, Universidade Federal do Pará, Altamira, Pará, 2014.

55. Marsaro Júnior AL, Silva RA, Silva WR, Lima CR, Flores AS, Ronchi-Teles B. New records of Anastrepha (Diptera: Tephritidae), its hosts and parasitoids in the Serra do Tepequém, Roraima state, Brazil. Rev. Agricul. 2010; 85:1520.

56. Marsaro Júnior $A L$, Adaime R, RonchiTeles B, Lima CR, Pereira PRVS. Anastrepha species (Diptera: Tephritidae), their hosts and parasitoids in the extreme north of Brazil. Biota Neotrop. 2011; 11(4):117-123.

DOI: $\quad$ https://doi.org/10.1590/S167606032011000400012

57. Azevedo TS, Vasconcelos AS, Santos RS, Sousa MSM, Adaime R. Levantamento de moscas frugívoras em dois municípios do Estado do Acre, Brasil. Biotemas. 2018; 31(3):25-31.
58. Silva NM. Estudos sobre competição interespecífica entre espécies de Anastrepha (Diptera; Tephritidae) e seus parasitóides no Amazonas. Full Professor's Thesis. Universidade Federal do Amazonas, Manaus, Amazonas, 1998.

59. Silva RA, Nascimento DB, Deus EG, Souza GD, Oliveira LSP. Hospedeiros e parasitóides de Anastrepha spp. (Diptera: Tephritidae) em Itaubal do Piririm, Estado do Amapá. Cienc Rural. 2007; 37(2):557560. DOI: https://doi.org/10.1590/S010384782007000200041

60. Silva RA, Jordão AL, Marinho CF, Sá LAN, Oliveira MRV. Braconidae parasitóides de moscas-das-frutas em quatro municípios do Estado do Amapá. In: 9o Simpósio de Controle Biológico, Recife, Pernambuco, 2005.

61. Sousa MSM, Jesus-Barros CR, Yokomizo GK, Lima AL, Adaime R. Ocorrência de moscas-das-frutas e parasitoides em Spondias mombin L. em três municípios do estado do Amapá, Brasil. Biota Amaz. 2016; 6(2):50-55.

62. Silva RA, Xavier SLO, Souza Filho MF, Silva WR, Nascimento DB, Deus EG. Frutíferas hospedeiras e parasitóides (Hym., Braconidae) de Anastrepha spp. (Dip., Tephritidae) na llha de Santana, Estado do Amapá, Brasil. O Biológico, 2007.

63. Castilho AP, Silva LC, Sousa MSM, Santos JEV, Lemos WP, Adaime R. Novas associações de Tephritidae e Lonchaeidae (Diptera) e suas plantas hospedeiras na Amazônia Oriental. Biotemas. 2019; 32(3):65-72.

DOI:https://doi.org/10.5007/2175-

7925.2019v32n3p65

64. Ayres ÁR, Santos PRF, Cavalcante IP, Santos FR, Araújo FLS. Ocorrência de moscas-das-frutas e seus parasitoides obtidos de frutos comercializados em feiras livres no Município de CastanhalPará. In: 26ㅇ Congresso Brasileiro de Entomologia; 9o Congresso Latinoamericano de Entomologia, Maceió, Alagoas, 2016.

65. Ayres AR. Moscas-das-frutas (Diptera: Tephritidae) na região nordeste do Pará. Doctoral Thesis, Universidade Federal Rural do Semiárido, Mossoró, Rio Grande do Norte, 2015.

66. Silva LC, Lemos WP, Oliveira TA. Cultivos de acerola abrigam diferentes espécies de parasitoides de Anastrepha obliqua 
(Macquart) (Dip., Tephritidae) no polo de fruticultura de Tomé-Açu, Pará. In: 250 Congresso Brasileiro de Entomologia, Goiânia, Goiás, 2014.

67. Souza NS. Interações tritróficas entre moscas-das-frutas, suas plantas hospedeiras e seus parasitoides nas Regiões Nordeste e Sudeste do Estado do Pará. Master's Dissertation, Universidade Federal do Pará, Belém, Pará, 2014.

68. Sousa MSM, Santos JCR, Jesus CR, Yokomizo GKI, Deus EG, Pereira JF, Adaime R. Goiabeiras comuns contribuem para expansão da área de distribuição de Bactrocera carambolae na Amazônia brasileira. In: Pacheco JTR, Kawanishi JY, Nascimento $R$, orgs. Meio Ambiente e Desenvolvimento Sustentável. Paraná: Atena; 2019.

69. Souza MSM, Pereira JDB, Oliveira MN, Lemos LN, Jesus CR, Michelotto MD, Silva RA. Infestação de goiaba (Psidium guajava L.) em dois estágios de maturação por moscas-das-frutas (Diptera: Tephritidae) em Tartarugalzinho, AP. In: 1응 Encontro Amapaense de Pesquisa Entomológica, Macapá, Amapá, 2008.

70. Thomazini MJ, Albuquerque ES. Parasitóides (Hymenoptera: Braconidae) de Anastrepha Schiner (Diptera: Tephritidae) no estado do Acre. Acta Amaz. 2009; 39(1):245-248. DOI: https://doi.org/10.1590/S004459672009000100030

71. Pereira JDB, Buriti DP, Lemos WP, Silva WR, Silva RA. Espécies de Anastrepha Schiner (Diptera: Tephritidae), seus hospedeiros e parasitóides nos Estados do Acre e Rondônia, Brasil. Biota Neotrop. 2010; 10 (3):441-446.

72. Creão MIP. Moscas-das-frutas (Diptera: Tephritidae): espécies, distribuição, medidas da fauna e seus parasitóides (Hymenoptera: Braconidae) no Estado do Amapá. Master's Dissertation, Instituto Nacional de Pesquisas da Amazônia / Universidade Federal do Amazonas, Manaus, Amazonas, 2003.

73. Adaime R, Sousa MSM, Jesus-Barros CR, Deus EG, Pereira JF, Strikis PC, SouzaFilho MF. Frugivorous flies (Diptera: Tephritidae, Lonchaeidae), their host plants, and associated parasitoids in the extreme north of Amapá State, Brazil. Fla Entomol. 2017; 100(2):316-324

74. Silva WR, Jesus CR, Silva RA. Infestação natural de taperebá (Spondias mombin L.,
Anacardiaceae) por Anastrepha spp. (Diptera: Tephritidae), no município de Afuá, Pará. O Biológico. 2006; 68:810-812.

75. Ohashi OS, Dohara R, Zucchi RA, Canal NA. Ocorrência de Anastrepha obliqua (Macquart, 1835) (Dip, Tephritidae) em acerola (Malpighia punicifolia L.) no Estado do Pará. An. Soc. Entomol. Brasil. 1997; 26(2):389-390.

DOI: $\quad$ https://doi.org/10.1590/S030180591997000200024

76. Castilho AP. Índices de infestação e parasitismo de Anastrepha serpentina (Wiedemann) (Dip. Tephritidae) em diferentes sistemas de cultivo de laranja em Capitão Poço, Pará. Master's Dissertation, Universidade Federal do Pará, Belém, Pará, 2013.

77. Amorim JEL. Diversidade de espécies de Anastrepha (Diptera: Tephritidae), seus parasitóides e hospedeiros em quintais agroflorestais no Estado de Roraima. Master's Dissertation, Universidade Federal do Amazonas, Manaus, Amazonas, 2003.

78. Adaime R, Jesus-Barros CR, Souza-Filho MF. Moscas-das-frutas (Diptera: Tephritidae) obtidas de frutos comercializados em feiras públicas de Macapá, Amapá. Amapá: Embrapa, Boletim de pesquisa e desenvolvimento, 85; 2014.

79. Ronchi-Teles B, Dutra VS, Tregue Costa AP, Aguiar-Menezes EL, Mesquita ACA, Silva JG. Natural host plants and native parasitoids associated with Anastrepha pulchra and other Anastrepha species (Diptera: Tephritidae) in Central Amazon, Brazil. Fla Entomol. 2011; 94(2):347349.

DOI: $10.1653 / 024.094 .0232$

80. Marsaro Júnior AL, Ronchi-Teles $B$, Pereira JDB, Lima CR, Silva Júnior RJ, Silva RA. Associação de Doryctobracon areolatus (Hymenoptera: Braconidae) com Anastrepha spp. (Diptera: Tephritidae) no município de Pacaraima, Estado de Roraima, Brasil. In: 11ㅇ Simpósio de controle biológico, Bento Gonçalves, Rio Grande do Sul, 2009.

81. Chaves EB. Diversidade de espécies de moscas-das-frutas (Anastrepha spp.) na cultura do araçá-boi (Eugenia stipitata McVaugh) em duas áreas no município de Manaus-AM. Master's Dissertation, Instituto Nacional de Pesquisas da Amazônia / Universidade Federal do 
Amazonas, Manaus, Amazonas; 2016.

82. Lemos WP, Araujo SCA, Silva RA, Silva WR. Parasitóides de Anastrepha obliqua (Macquart) (Dip., Tephritidae) em pitangueira no Município de Belém, Pará. In: 23으 Congresso Brasileiro de Entomologia, Natal, Rio Grande do Norte, 2010.

83. Ayres AR, Pinto MMD, Silva RS, Queiroz LGN, Rodrigues ANC. Moscas-das-frutas e seus parasitoides em plantio de acerola no município de Castanhal - PA. In: 26응 Congresso Brasileiro de Entomologia, 9응 Congresso Latino-americano de Entomologia, Maceió, Alagoas, 2016.

84. Façanha TP. Sistemas de cultivos de agricultores familiares: Diversidade de moscas-das-frutas, seus hospedeiros e inimigos naturais em Igarapé-Açú e Marapanim, Pará. Master's Dissertation, Universidade Federal do Pará, Belém, Pará, 2017.

85. Jesus CR, Silva RA, Souza Filho MF, Deus EG, Zucchi RA. First Record of Anastrepha pseudonomala Norrbom (Diptera: Tephritidae) and its Host in Brazil. Neotrop. Entomol. 2010; 39(6):1059-1060. DOI: $\quad$ https://doi.org/10.1590/S1519566X2010000600036

86. Ronchi-Teles B, Dutra VS, Silva JG. Host Plant of Anastrepha pulchra (Diptera: Tephritidae) in Central Amazon, Brazil Mistaken Identity Resolved. Fla Entomol. 2011; 94(3):719-720. DOI: https://doi.org/10.1653/024.094.0347

87. Lemos WP, Castilho AP, Araujo MR, Silva RA, Kato OR. Parasitismo de Anastrepha serpentina (Wiedemann) (Dip., Tephritidae) em diferentes sistemas de cultivos de laranja no município de Capitão Poço, Pará. In: 13o Simpósio de Controle Biológico, Bonito, Mato Grosso do Sul, 2013.

88. Lemos LN, Deus EG, Nascimento DB, Jesus-Barros CR, Costa-Neto SV, Adaime R. Species of Anastrepha (Diptera: Tephritidae), their host plants, and parasitoids in small fruit production areas in the State of Amapá, Brazil. Fla Entomol. 2017; 100(2):403-410. DOI: 10.1653 / 024.100 .0201

89. Silva RA, Pereira JDB, Lemos LN, Jesus CR, Lima AL, Lima CR. Novos registros de hospedeiros de Anastrepha striata Schiner (Diptera: Tephritidae) no Estado do Amapá, Brasil. O Biológico, 2009.
90. Marsaro Júnior AL, Lovato L, Ronchi-Teles B, Silva RA, Griffel SCP. Levantamento de hospedeiros e parasitóides de Anastrepha spp. (Diptera: Tephritidae) no município de Boa Vista, Estado de Roraima. In: 22응 Congresso Brasileiro de Entomologia, Uberlândia, Minas Gerais, 2008.

91. Adaime R, Jesus-Barros CR, Uramoto K, Norrbom AL, Zucchi RA. First record of Anastrepha zacharyi Norrbom (Diptera, Tephritidae) in Brazil, and notes on its host plant and parasitoid. Proc. Entomol. Soc. Wash. 2016; 118(4):636-640.

DOI: 10.4289/0013-8797,118.43636

92. Ronchi-Teles $B$, Marsaro Júnior $A L$, Lovato L, Silva RA. Ocorrência de Anastrepha zenildae Zucchi (Diptera: Tephritidae) e seu parasitóide em frutos de Ziziphus mauritiana (Rhamnaceae) em Roraima. In: 22 Congresso Brasileiro de Entomologia, Uberlândia, Minas Gerais, 2008.

93. Zucchi RA, Marinho CF, Silva RA. First Record of the Fruit Fly Parasitoid Doryctobracon crawfordi (Viereck) (Hymenoptera: Braconidae) in Brazil. Neotrop Entomol. 2011; 40(6):711-712. DOI: $\quad$ https://doi.org/10.1590/S1519566X2011000600014

94. Silva WR, Silva RA. Levantamento de moscas-das-frutas e de seus parasitóides no Município de Ferreira Gomes, Estado do Amapá. Cienc Rural. 2007; 37(1):265268.

95. Santos FRS, Silva CM, Santos GJ, Coimbra TS, Santos WS. Parasitóides (Hymenoptera: Braconidae) associados à Anastrepha (Diptera: Tephritidae) em frutos da cajazeira no município de Araguatins-TO. In: 13으 Simpósio de Controle Biológico. Bonito, Mato Grosso do Sul, 2013.

96. Nascimento DB, Adaime R, Cunha AC, Silva JG. Influência dos parâmetros biométricos de frutos de Spondias mombin L. sobre os índices de infestação por Anastrepha spp. (Diptera: Tephritidae) e parasitismo. Biota Amaz. 2015; 5(3):8387.

DOI: $\quad$ http://dx.doi.org/10.18561/21795746/biotaamazonia.v5n3p83-87

97. Jesus CR, Pereira JDB, Oliveira MN, Silva RA, Souza Filho MF, Costa Neto SV, Marinho CF, Zucchi RA. New records of fruit flies (Diptera: Tephritidae), wild hosts and parasitoids (Hymenoptera: Braconidae) in the Brazilian Amazon. Neotrop Entomol. 2008; 37(6):733-734. 
DOI: https://doi.org/10.1590/S1519566X2008000600017

98. Deus EG, Silva RA. Novo registro de hospedeiro para Anastrepha fraterculus
(Wiedemann) e Anastrepha zenildae Zucchi no Brasil e parasitóides associados. O Biológico; 2009.

(9) 2021 Sousa et al.; This is an Open Access article distributed under the terms of the Creative Commons Attribution License (http://creativecommons.org/licenses/by/4.0), which permits unrestricted use, distribution, and reproduction in any medium, provided the original work is properly cited.

\section{Peer-review history:}

The peer review history for this paper can be accessed here: https://www.sdiarticle4.com/review-history/73363 